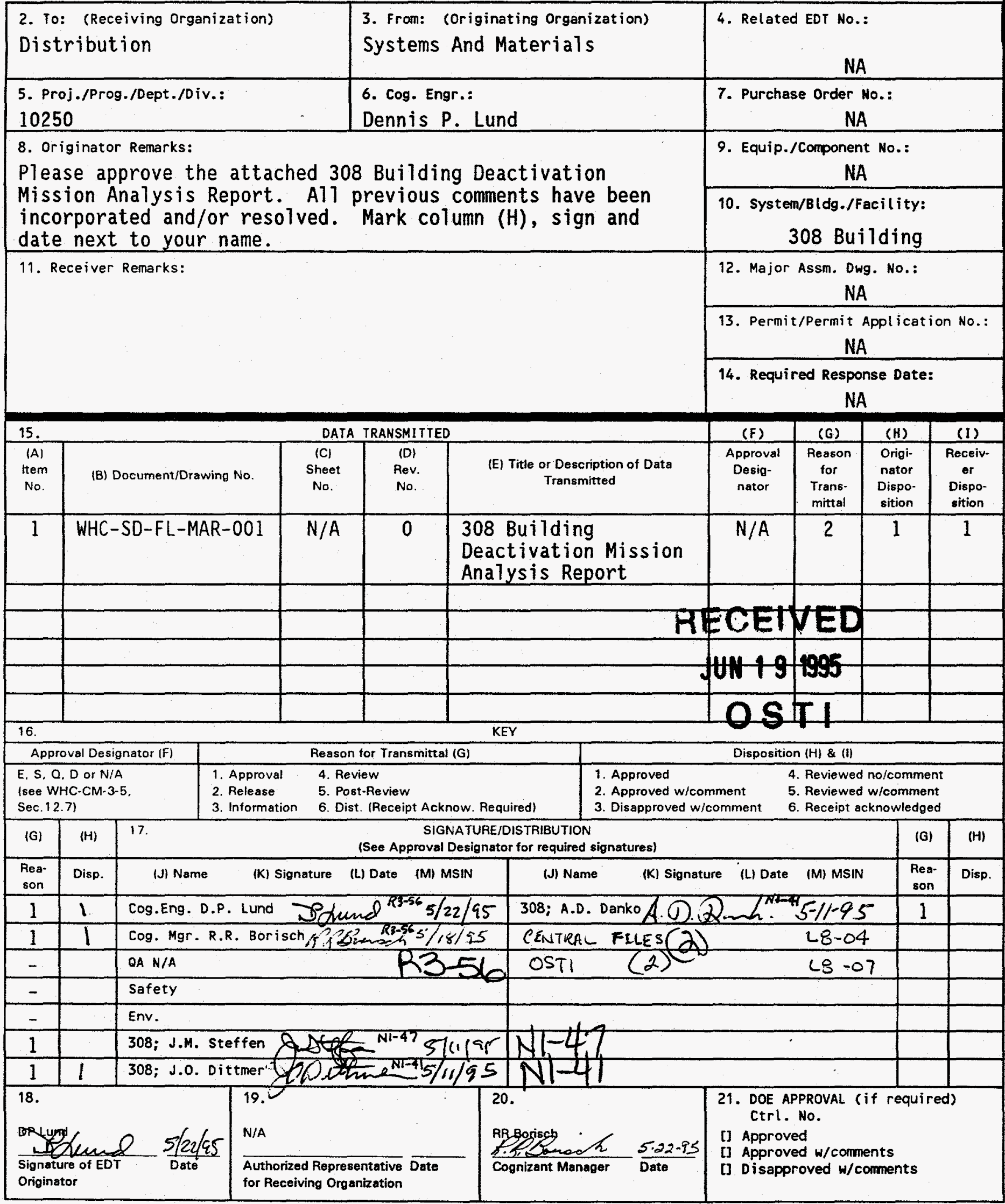




\section{DISCLAIMER}

Portions of this document may be illegible in electronic image products. Images are produced from the best available original document. 


\section{RELEASE AUTHORIZATION}

Document Number: WHC-SD-FL-MAR-001, Rev. 0

Document Title: 308 BUILDING DEACTIVATION MISSION ANALYSIS REPORT

Release Date: $\quad 5 / 24 / 95$

This document was reviewed following the procedures described in WHC-CM-3-4 and is:

APPROVED FOR PUBLIC RELEASE

WHC Information Release Administration Specialist:

$$
\text { Chris Ytillingtaro }
$$

TRADEMARK DISCLAIMER. Reference herein to any specific commercial product, process, or service by trade name, trademark, manufacturer, or otherwise, does not necessarily constitute or imply its endorsement, recommendation, or favoring by the United states Government or any agency thereof or its contractors or subcontractors.

This report has been reproduced from the best available copy. Available in paper copy and microfiche. Printed in the United States of America. Available to the U.S. Department of Energy and its contractors from:

U.S. Department of Energy

office of Scientific and Technical Information (OSTI)

P.0. Box 62

Oak Ridge, TN 37831

Telephone: (615) 576-8401

Available to the public from:

U.S. Department of Commerce

National Technical Information Service (NTIS)

5285 Port Royal Road

Springfield, VA 22161

Telephone: (703) 487-4650 


\section{SUPPORTING DOCUMENT}

1. Total Pages 20

\begin{tabular}{|l|l|l|}
\hline $\begin{array}{l}\text { 2. Title } \\
308 \text { Building Deactivation Mission Analysis Report }\end{array}$ & $\begin{array}{l}\text { 3. Number } \\
\text { WHC-SD-FL-MAR-001 }\end{array}$ & $\begin{array}{l}\text { 4. Rev No. } \\
0\end{array}$ \\
\hline $\begin{array}{l}\text { 5. Key Hords } \\
\text { 308 Building Mission, Mission Analysis Report, 308 } \\
\text { Building Deactivation Mission }\end{array}$ & $\begin{array}{l}\text { 6. Author } \\
\text { Name: DP Lund }\end{array}$ \\
& Signature \\
& organization/Charge Code10250/K123C \\
\hline
\end{tabular}

7. Abstract

\section{DISCLAIMER}

This report was prepared as an account of work sponsored by an agency of the United States Government. Neither the United States Government nor any agency thereof, nor any of their employees, makes any warranty, express or implied, or assumes any legal liability or responsibility for the accuracy, completeness, or usefulness of any information, apparatus, product, or process disclosed, or represents that its use would not infringe privately owned rights. Reference herein to any specific commercial product, process, or service by trade name, trademark, manufacturer, or otherwise does not necessarily constitute or imply its endorsement, recommendation, or favoring by the United States Government or any agency thereof. The views and opinions of authors expressed herein do not necessarily state or reflect those of the United States Government or any agency thereof.

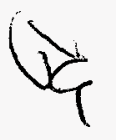

8. RELEASE STAMP

OFFIOIAL RELEASE

Br WHO

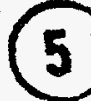

$$
\begin{gathered}
\text { DATE MAY } 241995 \\
\text { Ata } 4
\end{gathered}
$$




\title{
308 BUILDING DEACTIVATION MISSION ANALYSIS REPORT
}

March 30, 1995

\author{
WESTINGHOUSE HANFORD COMPANY \\ P. 0. BOX 1970 \\ Richland, WA 99352
}

DISTRIBUTION OF THIS DOCUMENT IS UNLIMITED 
WHC-SD-FL-MAR-001 Revision 0

TABLE OF CONTENTS

1.0 INTRODUCTION ..................... . . . . . .

1.1 PURPOSE ........................ 1 . . .

1.2 BACKGROUND $\ldots \ldots \ldots \ldots \ldots \ldots \ldots$

1.3 PROJECT SCOPE .................. . . . . .

1.4 MISSION STATEMENT $\ldots \ldots \ldots \ldots$

2.0 MISSION ANALYSIS ..................... 2-1

2.1308 BUILDING PROBLEM STATEMENT ............ 2-1

2.2 PROJECT OBJECTIVES ................... 2-1

2.3 MISSION DEFINITION .................. 2-1

2.3 .1 INITIAL CONDITIONS $\ldots \ldots \ldots . \ldots 2-2$

2.3.2 PHYSICAL BOUNDARIES ............. 2- 2-4

2.3 .3 EXTERNAL INTERFACES .............. 2-. 24

2.3 .4 FINAL CONDITIONS ............. 2-4

2.3 .5 CONSTRAINTS . . . . . . . . . . . . 2-6

2.3 .6 RESOURCES ................. 2- 2-9

2.4 MISSION EVALUATION . . . . . . . . . . . . 2-9

2.4 .1 MISSION RISK AREAS/FACTORS $\ldots \ldots . . . \ldots 2-9$

2.4 .2 MEASURES OF EFFECTIVENESS . . . . . . . . . . 2-10

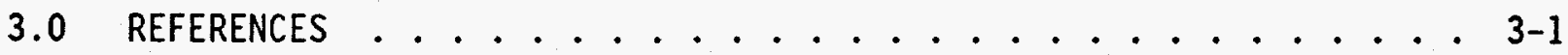

4.0 GLOSSARY ......................... . . . . . 


\section{WHC-SD-FL-MAR-001 Revision 0}

\section{LIST OF FIGURES}

Figure 1. 308 BUILDING DEACTIVATION MISSION .......... 2-3 


\subsection{INTRODUCTION}

\subsection{PURPOSE}

This report presents the results of the 308 BUILDING (Fuels Development Laboratory) Deactivation Project mission analysis. Hanford systems engineering (SE) procedures call for a mission analysis. The mission analys is is an important first step in the SE process. The functions and requirements to successfully accomplish this mission, the selected alternatives and products will later be defined using the SE process.

\subsection{BACKGROUND}

The 308 BUILDING was a standby nuclear fuel fabrication facility which was used to develop, test, and fabricate plutonium and uranium fueled powders, pellets, test pins and assemblies, and driver fuel assemblies for the Fast Flux Test Facility (FFTF) and other nuclear reactors in the USA and other countries. It also contains a TRIGA reactor that was used for neutron radiography testing of FFTF fuel. The facility plant was originally constructed in 1960 and has been expanded many times, with the last being in 1979. The 308 BUILDING was operated until October 1990, when DOE-Richland Operations Office (RL) directed Westinghouse Hanford Company (WHC) to deactivate the building. DOE-RL also directed WHC to transition the TRIGA reactor from shutdown to standby on November 1990.

\subsection{PROJECT SCOPE}

The scope of the 308 BUILDING Deactivation is defined as including:

- Deactivation of the 308 BUILDING, and facility utilities. Deactivation of the 308 BUILDING is well under way. The TRIGA reactor core has been defueled, fuel assemblies are stored in racks in the pool and the reactor has been transitioned to a TRIGA Fuel Storage Basin. The main Process Building, except for the ANNEX that houses the TRIGA Fuel Storage Basin and adjoining vacant rooms, has been deactivated and some holdup of stabilized plutonium and uranium remains in the glove boxes, radiological enclosures, exhaust system, and some interior rooms. The office wing has been deactivated. Removal of TRIGA fuel assemblies, radioactive sources, miscellaneous equipment, the Fuel Storage Basin water, and shutdown of utilities is all that remains to complete deactivation of the 308 BUILDING. Specific turnover criteria has been developed and negotiated with the decontamination and decommissioning (D\&D) organization and will be used to determine what needs to be done to deactivate the 308 BUILDING. This criteria is 
similar to the Hanford Surplus Facility Program Criteria (100 Area Projects generic acceptance criteria for D\&D).

- $\quad$ The 308 BUILDING P7ant configuration shall be and has been modified and controlled sufficiently to enable safety and regulatory compliance during deactivation. Records shall be and have been established and archived for reactivating D\&D essential systems and providing meaningful D\&D characterization information.

- Hazardous and radioactive materials either shall be or have been removed from the facility or stabilized sufficiently to ensure long-term safety and regulatory compliance, enable facility classification as non-occupied, and enable subsequent successful D\&D. The facility should comply with DOE-N-5480.6, Hanford Site Radiological Control Manual, as applicable to a non-occupied facility. Materials which require plant knowledge and expertise to ensure safe and compliant removal should also be removed. Fuel assemblies currently remain in the ANNEX which houses the TRIGA Fuel Storage Basin.

- Final facility configuration shall be and have ensured D\&D operations are not jeopardized, and facility safety and environmental protection can be maintained until D\&D.

- To achieve a non-occupied facility status, the following actions shall be performed. In some cases, the activities have already been completed and are noted, as such.

- Ventilation and monitoring equipment shall be eliminated, consolidated, relocated, housed, operated, and/or maintained such that facility entry frequency does not compromise the nonoccupancy status. The main Process Building (except for the ANNEX that houses the TRIGA Fue 1 Storage Basin facility and adjoining vacant rooms) and office wing ventilation has been deactivated. Remaining monitoring equipment has been routed through the TRIGA control room. Ventilation and monitoring equipment is active, but has been reduced (consistent with it being a Fuel Storage Basin) for the ANNEX that houses the TRIGA Fuel Storage Basin.

- Fire protection systems have been modified to a dry system to minimize system testing and maintenance and to reflect the non-occupied status. 
- Electrical to the main Process Building (except for the ANNEX that houses the TRIGA Fuel Storage Basin and adjoining vacant rooms) and office wing has been reduced and isolated. The only water supply services to the 308 BUILDING is pool make up water for the TRIGA Fuel Storage Basin. Utilities will be or have been terminated at the classical junction. Sanitary sewer systems have been capped at the floor level. Centralized services were utilized.

- The building steam system was deactivated, requiring building steam requirements to be eliminated. The ANNEX that houses the TRIGA Fuel Storage Basin and adjoining vacant rooms) uses electrical for heating.

- At completion of deactivation, the facility will be unoccupied, locked and maintained with minimum entry requirements.

\subsection{MISSION STATEMENT}

The purpose of the 308 BUILDING Deactivation Project is to establish a passively safe and environmentally secure configuration of the 308 BUILDING, and turnover the 308 BUILDING to D\&D. The project removes, reduces, and/or stabilizes the major remaining radioactive sources within the 308 BUILDING process building and removes the hazardous chemicals in the facility. There will be no active systems or utilities within the process buildings and office wing. During deactivation, all aspects of the safety envelop will be continually challenged, and appropriate portions maintained to ensure deactivation takes $\mathrm{place}$ in a safe and regulatory compliant manner. Stakeholders will be actively involved during deactivation. 


\subsection{MISSION ANALYSIS}

\subsection{BUILDING PROBLEM STATEMENT}

Because the 308 BUILDING, a plutonium facility, is located near the city of Richland, Washington, because the facility is no longer needed for fuel production, because the cost is high to maintain the safety envelope, and because deactivation reduces the operating cost; the DOE has ordered deactivation of the facility. Essentially, the problem is how to deactivate 308 BUILDING to a point where safe and compliant D\&D operations can take place with acceptable risk and where only minimum maintenance and surveillance is required to maintain the facility until D\&D.

\subsection{PROJECT OBJECTIVES}

- Establish a passively safe and environmentally secure configuration of the facility with no active internal functions or equipment within confinement, and retain that configuration until turnover to D\&D.

- Achieve a total yearly operating cost target of $\$ 1$ million/year at turnover to D\&D.

- Implement cost-effective, innovative approaches to ensure the required safety envelope is defined and maintained during deactivation.

- Achieve compliance with Environmental, Safety, and Health codes and standards during deactivation. Apply lessons learned from commercial deactivation experience.

- Involve stakeholders, as appropriate, in the development and execution of the 308 BUILDING Deactivation Project.

- Establish the 308 BUILDING Deactivation Project as a model for plutonium and highly enriched uranium fuel fabrication facility deactivations.

\subsection{MISSION DEFINITION}

In addition to the mission statement, the mission to deactivate 308 BUILDING can be further defined through an understanding of the initial conditions prior to deactivation, the final endpoint or conditions desired upon completion of the mission, the constraints under which the mission must be performed, and the resources that are available to enable the mission. The following paragraphs describe the initial and final conditions, the physical boundaries and programmatic interfaces, and the resources to achieve 308 
BUILDING deactivation. A diagram of the initial conditions, final conditions, constraints and resources required to perform the 308 BUILDING Deactivation Mission are shown in Figure 1.

\subsubsection{INITIAL CONDITIONS}

\section{LEGACY FACILITIES, EQUIPMENT AND NON-NUCLEAR MATERIALS}

The 308 BUILDING was a nuclear fuel fabrication facility which was used to develop, test, and fabricate plutonium and uranium fueled powders, pellets, test pins and assemblies, and driver fuel assemblies for the Fast Flux Test Facility (FFTF) and other nuclear reactors in the USA and other countries. The main Process Building, except for the ANNEX that houses the TRIGA Fuel Storage Basin facility and adjoining vacant rooms and the office wing have been cleaned out and deactivated. All equipment, components, furniture, and etc., have been removed. Hazardous and nonhazardous waste and materials have been removed or stabilized. HVAC has been shutdown; and electrical services greatly reduced. A dry fire system has been installed. Water and sewer have been shutdown. Less than 400 grams of plutonium oxide and slightly greater than 4 kilograms of depleted uranium oxide contamination is stabilized in the 55 remaining radiological enclosures such as gloveboxes and open faced hoods; and approximately 21 grams of plutonium oxide is stabilized in the exhaust ventilation system for the radiological enclosures. Some fixed surface contamination exists under paint and flooring materials in the process side of the 308 BUILDING.

The 308 BUILDING also houses a TRIGA reactor that was used for neutron radiography testing of FFTF fuel. The TRIGA reactor core has been defueled, and the reactor has been transitioned to a TRIGA Fuel Storage Basin. Fuel assemblies are stored in racks in the pool. The TRIGA reactor facility has been deactivated. 9,500 gallons of light water were removed. All of the remaining equipment, components, and furniture were removed. Hazardous and non-hazardous waste and materials have been removed or stabilized. HVAC was shutdown; and electrical services, greatly reduced.

In October 1990, DOE-Richland Operations Office (RL) directed Westinghouse Hanford Company (WHC) to deactivate the building. In November 1990, DOE-RL also directed WHC to transition the TRIGA reactor from shutdown to standby.

\section{LEGACY NUCLEAR MATERIALS}

The 308 Building has the following nuclear materials: $<400 \mathrm{~g}$ Plutonium Oxide; $>4 \mathrm{Kg}$ depleted Uranium Oxide; nominally $20 \%$ enriched $U^{235}$ ( 37 to 38 grams) irradiated fuel assemblies (101 each); non-irradiated fuel assemblies ( 3 each); and 4 radioactive 


\title{
Figure 1. 308 BUILDING DEACTIVATION MISSION
}

\author{
CONSTRAINTS \\ $\begin{array}{cccc}\text { DEF WK } & \text { DIRECTION MISSION } & \text { TRANSFER } \\ \text { PKG } & \& & \text { REQMENTS } & \text { AGREEMENTS }\end{array}$ \\ CONTROL
}

INITIAL CONDITIONS

LEGACY FACILITIES, EQUIPMENT \& NON NUCLEAR MATERIALS

$\tilde{\omega}$

LEGACY NUCLEAR MATERIALS

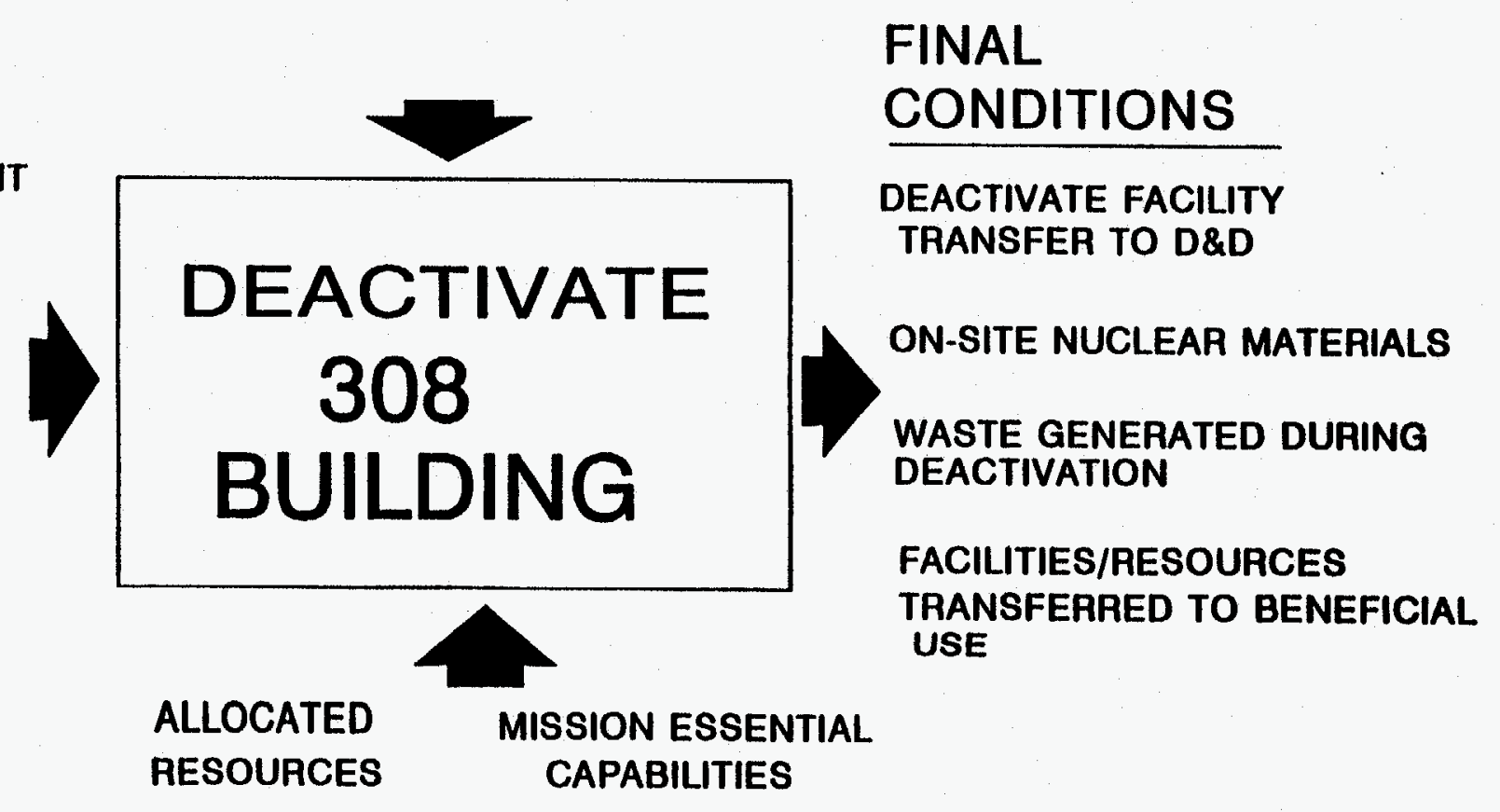


sources in the TRIGA Fuel Storage Basin and reactor hall would be removed and stored in another facility.

\subsubsection{PHYSICAL BOUNDARIES}

The physical boundaries of the 308 BUILDING are the exterior walls of main process building including all expansions such as the ANNEX which houses the TRIGA Fuel Storage Basin. The office wing is also included.

\subsubsection{EXTERNAL INTERFACES}

Interfaces occur when information, material or energy are exchanged between two entities. The 308 BUILDING interfaces with the following areas including those agencies which impose requirements:

- Federar Agencies

- State and Local Governments

- Confederated Tribes

- DOE Headquarters and Field Office

- DOE Laboratories

- Other Hanford Programs and Projects

- Solid Waste

- Liquid Effluent

- PFP Transition Project

- Site Environmental Monitoring

- Site Infrastructure

- D\&D Contractor

- Stakeholders

\subsubsection{FINAL CONDITIONS}

\section{DEACTIVATED FACILITY(s)}

The only deactivated facility will be the 308 BUILDING.

Specific turnover criteria has been developed and negotiated with the D\&D organization and will be used to determine what needs to be done to deactivate the 308 BUILDING. This criteria is similar to the Hanford Surplus Facility Program Criteria (100 Area 
Projects generic acceptance criteria for D\&D). Deactivated facilities along with the D\&D data package are transferred to the Environmental Restoration (ER) activity for D\&D. In some cases, D\&D operations may not begin before many years, making it essential that the facilities be placed in a minimum safe, stable and environmentally compliant condition, that requires minimal maintenance and surveillance and results in an unoccupied facility status. Deactivated facilities shall not pose undue risk to future D\&D activities.

The condition of the 308 BUILDING at turnover to D\&D will be a deactivated main process building and office wing that have been cleaned out. All equipment, components, and furniture will be removed. Hazardous and non-hazardous waste and materials will be either removed or stabilized. Electrical services will be greatly reduced. Dry fire system will be installed. HVAC, water, and sewer will be shutdown. The facility will be deactivated. Less than 400 grams of plutonium oxide and a small amount of uranium oxide contamination is stabilized in the 55 remaining radiological enclosures, such as, gloveboxes and open faced hoods. Approximately 21 grams of plutonium oxide is stabilized in the exhaust ventilation system for the radiological enclosures. Some fixed surface contamination exist under paint and flooring materials in the process side, except for the ANNEX that housed the TRIGA Fuel Storage Basin facility and adjoining vacant rooms of the 308 BUILDING.

Included in the facility condition at turnover will be the removal of TRIGA Fuel Storage Basin's 9,500 gallons of 1ight water and all equipment and components. The TRIGA Fuel Storage Basin facility will also be deactivated. Low level activation of the TRIGA core basket and surrounding components and structure will remain.

A D\&D data package that documents and describes what has been done to deactivate the 308 BUILDING and current conditions will be transferred to D\&D contractor at their takeover of the 308 BUILDING.

\section{ON-SITE NUCLEAR MATERIALS}

Nuclear materials must be either removed, treated and/or stabilized. Nuclear materials that must be removed include the nominally $20 \%$ enriched $U^{235}$ ( 37 to 38 grams) irradiated fuel assemblies (101 each) and non-irradiated fuel assemblies ( 3 each) along with 4 radioactive sources that remain in the TRIGA Fuel Storage Basin and reactor hall. 


\section{WASTES GENERATED DURING DEACTIVATION}

Wastes generated during deactivation were, and are anticipated to be, low level waste (LLW) and hazardous waste (HW), which would and could go to solid waste.

\section{FACILITIES/RESOURCES TRANSFERRED TO BENEFICIAL USE}

Equipment, furniture, and components will be redeployed to other programs or excessed. Truck and trailer will be redeployed. Personnel have been redeployed to other programs. Three TRIGA fuel assemblies will be transferred to another TRIGA reactor.

\subsubsection{CONSTRAINTS}

\section{DEFINED WORK PACKAGES}

Defined work packages at this level really constitute the technical baseline for the current fiscal year. They define the intended work scope in broad terms, generally at a program level.

\section{DIRECTION AND CONTROL}

Direction and control is provided from the Manage function as described in WHC-EP-0722 "Systems Engineering Functions and Requirements for the Hanford Cleanup Mission: First Issue". Direction is generally provided at a program level. The Manage function must integrate all program and project efforts and make site level decisions to achieve the best overall results at the site level.

\section{MISSION REQUIREMENTS}

Mission requirements are limits and performance criteria on system design solutions imposed from authority outside the cleanup mission. On a broad level, mission requirements consist of compliance with the following:

- Mission constraints that are self imposed upon the cleanup mission are as follows:

- Design solutions must inherently improve the safety posture of the site with respect to subsequent operations.

- Only cost effective design solutions will be considered.

- Stakeholder interests must be included in alternative definition and selection. 
- Successful alternatives must be capable of resulting in, or contributing to, the rapid progress needed to sustain mission momentum and support.

- The cleanup work must not adversely affect other ongoing or project Hanford Site missions.

- Public Law (PL); these are federal legislative statutory laws that are generated by a specific session of Congress. The National Defense Authorization Report in connection with the permanent closure of DOE Defense Nuclear Facilities is an example of one applicable PL.

- United States Code (USC); these are laws of a general and permanent nature under arrangement of official code of laws of the United States. Examples include: Clean Water Act; National Environmental Policy Act; Resource Conservation and Recover Act of 1976; Comprehensive Environmental Response, Compensation, and Liability Act of 1980; and the Nuclear Waste Policy Act.

- Federal Register (FR); these include, but are not limited to, proposed and final federal agency regulations, policies, documents required to be published by an act of Congress and other federal agency documents of public interest. The Final Environmental Impact Statement for the Disposal of Hanford Defense High-Level, Transuranic and Tank Wastes, Hanford Site, Richland, Washington: Decision of Records is an example of a FR document.

- Code of Federal Regulations (CFR); these are a codification of the general and permanent rules published in the Federal Register by the Executive departments and agencies of the Federal Government. Examples include: Packaging and Transportation of Radioactive Material; Occupational Safety and Health Administration; Identification and Listing of Hazardous Waste; Standards Applicable to Generators of Hazardous Waste; and Shippers-General Requirements for Shipments and Packaging.

- Hanford Federal Facility Agreement and Consent Order (89-10, Rev. 1); this is the agreement between DOE, EPA, and the Washington State Department of Ecology and is more commoniy known as the Tri-Party Agreement. The Tri-Party Agreement identifies milestones that quantify actions toward Hanford Site compliance with the Resource Conservation and Recovery Act of 1976, the Comprehensive Environmental Response, Compensation and Liability Act of 1980, and the Washington State Hazardous Waste Management Act. 
- Washington Administrative Code (WAC); these are a codification of general and permanent rules published in the Washington State Register by the agencies of the State of Washington. Examples include: Dangerous Waste Regulations; Washington Ambient Air Quality Standards and Emission Limits for Radionuclides; Washington Standard for Protection Against Radiation; and Transportation of Hazardous Materials.

- Revised Code of Washington (RCW); comprises all laws of a general and permanent nature under arrangement of official code of laws of the State of Washington. Examples include: Washington State Environmental Policy Act; Washington Radioactive Waste Act; Washington Industrial Safety and Health Act; and Washington Clean Air Act.

- Executive Order (EO); these are orders or regulations issued by the President, or administrative authority, that can have the effect of 1 aw if published in the Federal Register. Responses to Environmental Standards (Aug. 14, 1981; $46 \mathrm{FR}$ 42237) and Superfund Implementation (Feb. 23, 1987; 52 FR 2923) are examples of EOs.

- Secretary of Energy Notices (SEN); these convey direction on processes and procedures which control operations, design, procurements, etc.. SEN-35-91, Nuclear Safety Policy is an example of a SEN.

- U.S. Department of Energy Orders; these are 1ong-1asting directives stating policy or establishing standards of operation. Examples of DOE Orders include: Comprehensive Environmental Response, Compensation, and Liability Act Requirements; Radiation Protection of the Public and the Environment; National Environmental Policy Act Compliance Program; Environmental Protection, Safety and Health Protection Standards; and Radiation Protection for Occupational Workers.

- U.S. Department of Energy Notices; these are one-time or short-term (less than 1 year) instructions or information. Notices are used to provide immediate dissemination until the information can be incorporated into an order.

- Codes and Standards; these are national or international consensus documents written and critiqued by technical specialists versed in the field of interest. Usually these standards are generated by professional societies.

- U.S. Department of Energy Environmental Management Policy; these are guidelines formulated by the Assistant Secretary for Environmental Management or by the Secretary of Energy. 
- Westinghouse Hanford Company Controlled Manuals; these are internal company procedures that are intended to encompass all relevant requirements associated with activities covered in the procedure and describe how the activities need to be performed to ensure compliance. Examples include WHC-CM-4-3, Industrial Safety Manual; etc. . .

\section{TRANSFER AGREEMENT}

Transfer agreements provide the authority to make transfers of materials between various programs and projects on-site, or offsite. Authority for the transfer comes from the Manage function as described in WHC-EP-0722 "Systems Engineering Functions and Requirements for the Hanford Cleanup Mission: First Issue".

\subsubsection{RESOURCES}

\section{ALLOCATED RESOURCES}

Allocated resources primarily includes the budget and personnel necessary to carry out the current fiscal technical baseline defined by the Manage function as described in WHC-EP-0722 "Systems Engineering Functions and Requirements for the Hanford Cleanup Mission: First Issue".

\section{MISSION ESSENTIAL CAPABILITIES}

Mission essential capabilities include the expertise, facilities, equipment, infrastructure, supplies, information, services and technology to perform the 308 BUILDING Deactivation Project.

Typically, these are provided by the Acquire Mission Essential Capabilities function as described in WHC-EP-0722 "Systems

Engineering Functions and Requirements for the Hanford Cleanup Mission: First Issue".

\subsection{MISSION EVALUATION}

\subsubsection{MISSION RISK AREAS/FACTORS}

- Sufficient budget will be available to support the planned work for each fiscal year of deactivation. Insufficient budget will negatively impact the schedule for completion of deactivation activities.

- 308 BUILDING will be able to transfer the necessary nuclear and hazardous materials to other programs to meet the deactivation project turnover criteria. Inability to remove these materials will delay completion of deactivation. 
- Public involvement in the deactivation decisions can affect the scope of work and thus impact budget needs and effect the schedule for completion of deactivation.

- Changing requirements can effect the scope of work and thus impact budget needs and the schedule for completion of deactivation.

- Mission essential capabilities are not provided in a timely manner and to the degree necessary to ensure successful deactivation.

- Environmental impacts beyond those anticipated as a result of deactivation.

- Risk to workers beyond those anticipated as a result of deactivation.

- Timely decisions by management and other interfacing organizations to ensure minimal impact to deactivation.

- Ability to move the SNM, irradiated fuel, hazardous waste, and waste out of the 308 BUILDING due to NEPA issues, or no policy agreement on the disposition of the SNM, hazardous waste, and waste.

- Approval and implementation of the "Relocation of TRIGA Reactor Irradiated Fuel From 308 BUILDING" Environmental Assessment must be accomplished.

\subsubsection{MEASURES OF EFFECTIVENESS}

- SNM dispositioned or relocated to another facility with a storage mission or storage location.

- Deactivation of 308 BUILDING completed, successful, and approved with the 308 BUILDING turned over to D\&D.

- 308 BUILDING D\&D data package completed and accepted by D\&D. 


\section{WHC-SD-FL-MAR-001 Revision 0}

\subsection{REFERENCES}

9452199; March 29, 1994; Hanford Site Systems Engineering Management Plan; Westinghouse Hanford Company.

9453650; May 25, 1994; Hanford Site Systems Engineering Manual; Westinghouse Hanford Company.

WHC-EP-0722 Rev. 0; January 1994; Systems Engineering Functions and Requirements for the Hanford Cleanup Mission: First Issue; Westinghouse Hanford Company.

WHC-SD-FL-SSP-001 Rev. 0; May 1993; 308 BUILDING Shutdown Plan; Westinghouse Hanford Company.

WHC-SD-FL-DB-003 Rev. 0; October 1993; D\&D Facility Acceptance Criteria for 308 BUILDING; Westinghouse Hanford Company. 
WHC-SD-FL-MAR-001 Revision 0

\subsection{GLOSSARY}

This section contains the definition of words and phrases found in the text of this document.

\begin{tabular}{|c|c|}
\hline active & $\begin{array}{l}\text { This term describes the operational status of a process } \\
\text { or facility. When a facility is active, it is currently } \\
\text { operating or scheduled for operation. }\end{array}$ \\
\hline deactivation & $\begin{array}{l}\text { The transition of facilities to a state where the } \\
\text { buildings, chemical processing systems and infrastructure } \\
\text { are placed in a long term, low cost, minimum surveillance } \\
\text { and maintenance, safe condition and are ready for D\&D. A } \\
\text { facility enters deactivation when the need for a facility } \\
\text { to fulfill its current mission does not exist. }\end{array}$ \\
\hline$D \& D$ & $\begin{array}{l}\text { D\&D is decontamination and decommissioning and is } \\
\text { performed when no other missions are identified. The } \\
\text { objective of D\&D is to place the site in a long-term } \\
\text { radiologically safe condition. Dismantling and } \\
\text { decontamination, mothball for later dismantlement and } \\
\text { entombment are all D\&D options. }\end{array}$ \\
\hline ER & $\begin{array}{l}\text { ER is Environmental Restoration. It is an activity } \\
\text { contracted to the ER Contractor. They will perform D\&D } \\
\text { of facilities. }\end{array}$ \\
\hline holdup & $\begin{array}{l}\text { Holdup is residues, which contain Plutonium, that are } \\
\text { located in the facility process hardware, such as the } \\
\text { ventilation system. Holdup, depending on the quantity } \\
\text { and accessibility, might be removed as part of the } \\
\text { deactivation activities. }\end{array}$ \\
\hline $\begin{array}{l}\text { infrastructure } \\
\text { (facility) }\end{array}$ & $\begin{array}{l}\text { Facility infrastructure is the physical portions of the } \\
\text { facility which are implicit to the function of the } \\
\text { activities in the structure, such as the heating } \\
\text { ventilation, electricity etc. }\end{array}$ \\
\hline $\begin{array}{l}\text { infrastructure } \\
\text { (site) }\end{array}$ & $\begin{array}{l}\text { Includes all utility, support and other service systems } \\
\text { that interfere with a particular facility complex. } \\
\text { Within a facility complex ancillary facilities and } \\
\text { structures provide infrastructure support to the main } \\
\text { facility. }\end{array}$ \\
\hline interim storage & $\begin{array}{l}\text { The storage of stabilized materials until these materials } \\
\text { are transferred or dispositioned. The duration of } \\
\text { storage depends on the availability of suitable storage } \\
\text { locations and disposition instructions by the owners } \\
\text { (DOE). }\end{array}$ \\
\hline
\end{tabular}




\begin{tabular}{|l|l|}
\hline lay away & $\begin{array}{l}\text { This term describes the operational status of a process } \\
\text { or facility. A laid away process is not operable without } \\
\text { major repairs/upgrades, and no operations are planned. } \\
\text { This category is scheduled for decontamination and } \\
\text { decommissioning (D\&D). }\end{array}$ \\
\hline mission & $\begin{array}{l}\text { A mission is a narrative description of the ultimate } \\
\text { goals and highest purpose for an organizational unit, } \\
\text { facility or project. }\end{array}$ \\
\hline stabilize & $\begin{array}{l}\text { This is the process of treating (chemically or } \\
\text { physically) material to make it less hazardous. }\end{array}$ \\
\hline standby & $\begin{array}{l}\text { This term describes the operational status of a process } \\
\text { or facility. A facility in standby is not currently } \\
\text { operating, but it is operable after appropriate startup } \\
\text { checks and testing have been performed. In some cases } \\
\text { appropriate repairs and upgrades may be necessary. }\end{array}$ \\
\hline turnover & $\begin{array}{l}\text { Turnover is the transaction which transfers } \\
\text { responsibility from the current organizational unit } \\
\text { (Transition Projects) to the ER contractor. }\end{array}$ \\
\hline
\end{tabular}

